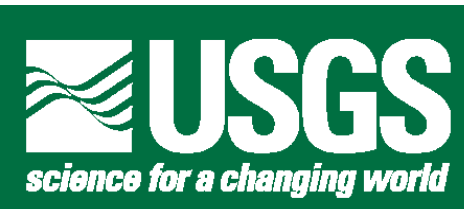

\title{
Principal Facts for Gravity Stations and Physical Property Measurements in the Lake Mead 30' by 60' quadrangle, Nevada and Arizona
}

By V.E. Langenheim 1, J.G. Davidson', M.L. Anderson ${ }^{1}$, and H.R. Blank, Jr. ${ }^{2}$

Open-File Report 99-435

Version 1.0

1999

Available online at http://geopubs.wr.usgs.gov/open-file/of99-435/

This report is preliminary and has not been reviewed for conformity with U.S. Geological Survey editorial standards. Any use of trade, product, or firm names is for descriptive purposes only and does not imply endorsement by the U.S. Government.

\section{U.S. DEPARTMENT OF THE INTERIOR U.S. GEOLOGICAL SURVEY}

${ }^{1} 345$ Middlefield Road, Menlo Park, CA 94025

${ }^{2}$ W 904 Riverside Avenue, Spokane, WA 99201 


\section{Introduction}

The U.S. Geological Survey (USGS) collected 811 gravity stations on the Lake Mead 30' by 60' quadrangle from October, 1997 to September, 1999. These data were collected in support of geologic mapping of the Lake Mead quadrangle. In addition to these new data, gravity stations were compiled from a number of sources (Table 1). These stations were reprocessed according to the reduction method described below and used for the new data. Density and magnetic susceptibility measurements were also performed on more than 250 rock samples.

Table 1. Data sources for the Lake Mead 30' by 60' quadrangle.

Source

U.S. Geological Survey, this report

Defense Mapping Agency

Kane and others (1979)

U.S. Geological Survey, 1980’s

Hoffman (1978)

Campagna (1990)

MIT field camp (1998)
Number of stations

811

328

65

59

194

33

83 $\underline{\text { Region }}$

Entire quadrangle

Entire quadrangle

Entire quadrangle

East of Overton Arm

West of Overton Arm

Overton Beach 7-1/2 minute

quadrangle

Lime Wash 7-1/2 minute quadrangle

The Lake Mead quadrangle ranges from $36^{\circ}$ to $36^{0} 30^{\prime}$ north latitude and from $114^{\circ}$ to $115^{\circ}$ west longitude (Fig. 1). It spans most of Lake Mead, the largest manmade lake in the United States, and includes most of the Lake Mead National Recreation Area. Its geology is very complex; Mesozoic thrust faults are exposed in the Muddy Mountains, Precambrian crystalline basement rocks are exhumed in tilted fault blocks near Gold Butte, extensive Tertiary volcanism is evident in the Black Mountains, and strike-slip faults of the right-lateral Las Vegas Valley shear zone and the left-lateral Lake Mead fault system meet near the Gale Hills. These gravity data and physical property measurements will aid in the 3-dimensional characterization of structure and stratigraphy in the quadrangle as part of the Las Vegas Urban Corridor mapping project.

\section{Gravity Data Sources and Reduction}

Gravity data in the Lake Mead 30' by 60' quadrangle and vicinity include 811 gravity stations obtained by the USGS from October, 1997 to September, 1999 (Fig. 2), 328 gravity stations from the Defense Mapping Agency, and 65 stations from Kane and others' (1979) compilation for the Bouguer gravity map of the Las Vegas $1^{0}$ by $2^{0}$ quadrangle (Fig. 3). An additional 59 gravity stations are from a USGS effort in the late 1980s and 310 stations from Hoffman (1978), Campagna (1990; written communication, 1998), and the Massachusetts Institute of Technology (MIT) field camp (C. Marone, written communication, 1998; Fig. 4). 


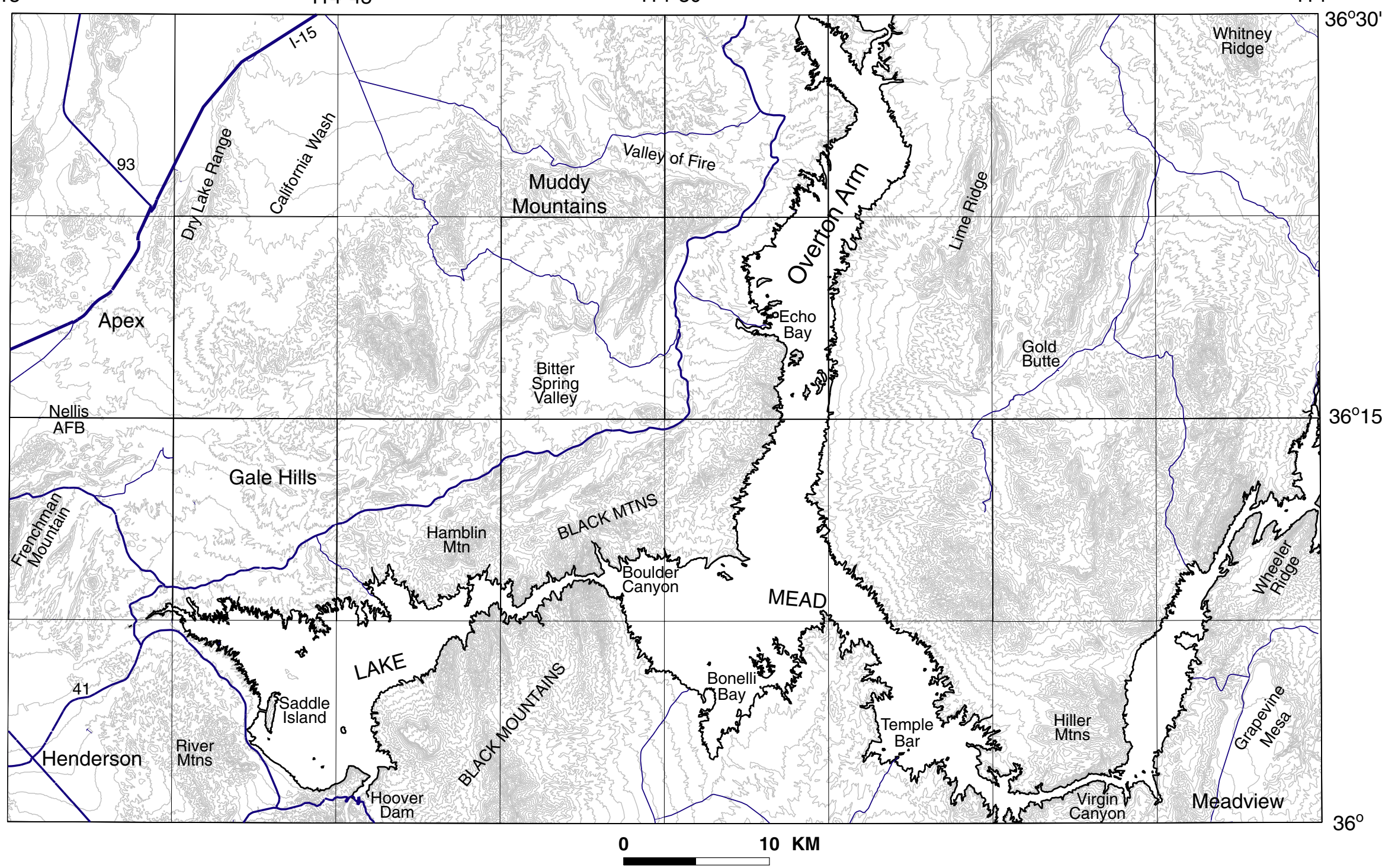




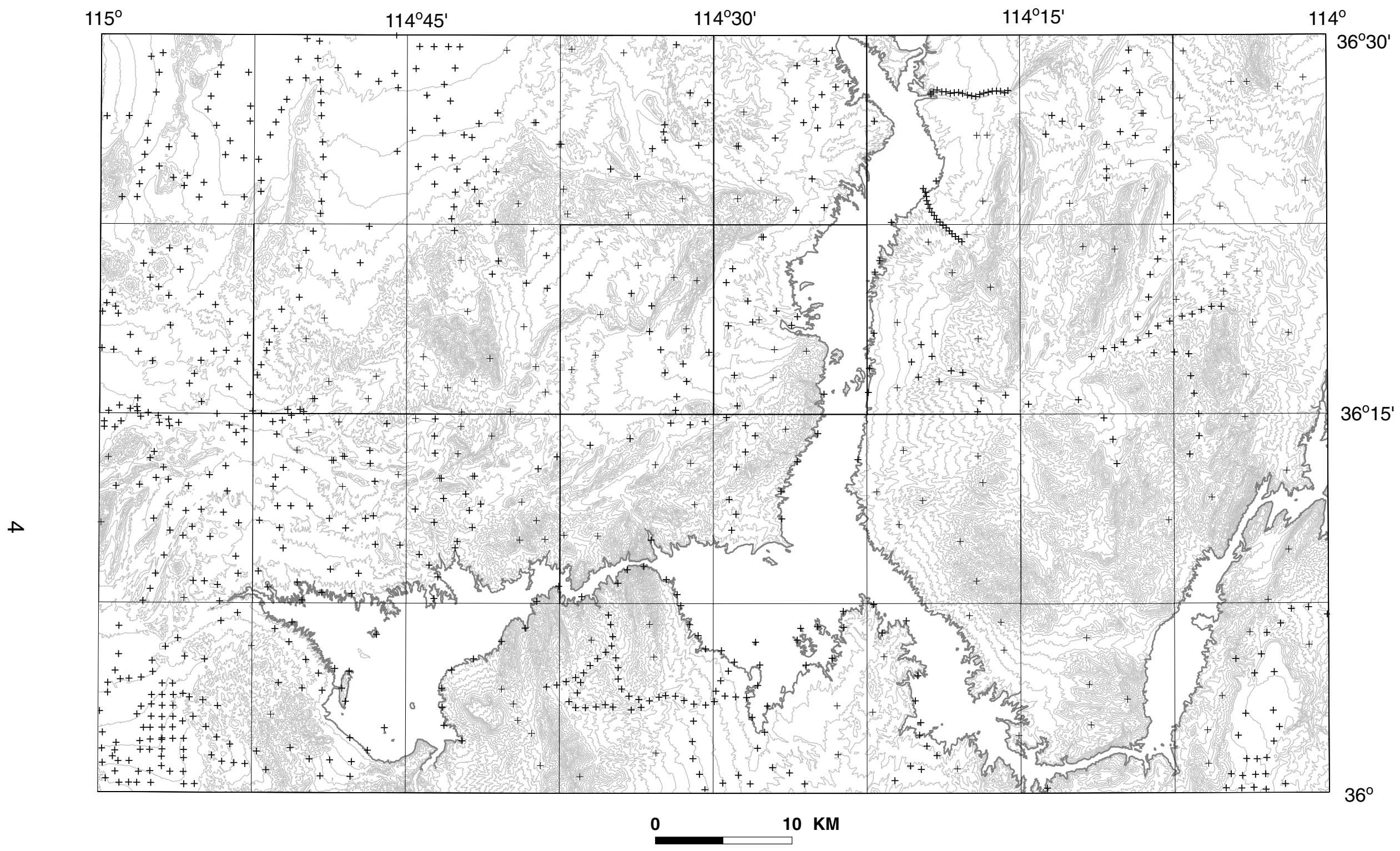

Figure 2. New U.S. Geological Survey stations. 


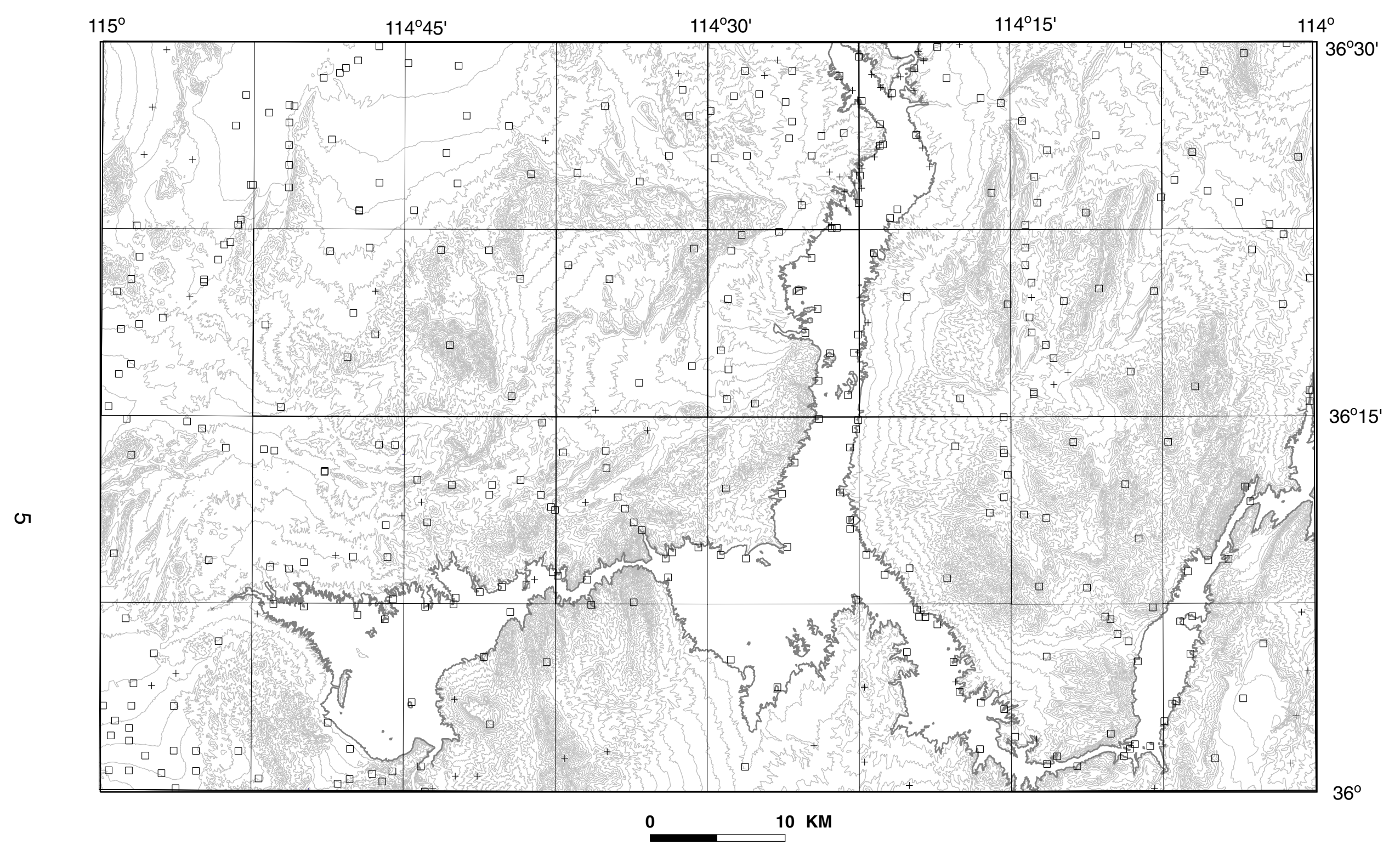

Figure 3. Stations from Defense Mapping Agency (squares) and Kane and others (1979; crosses). 


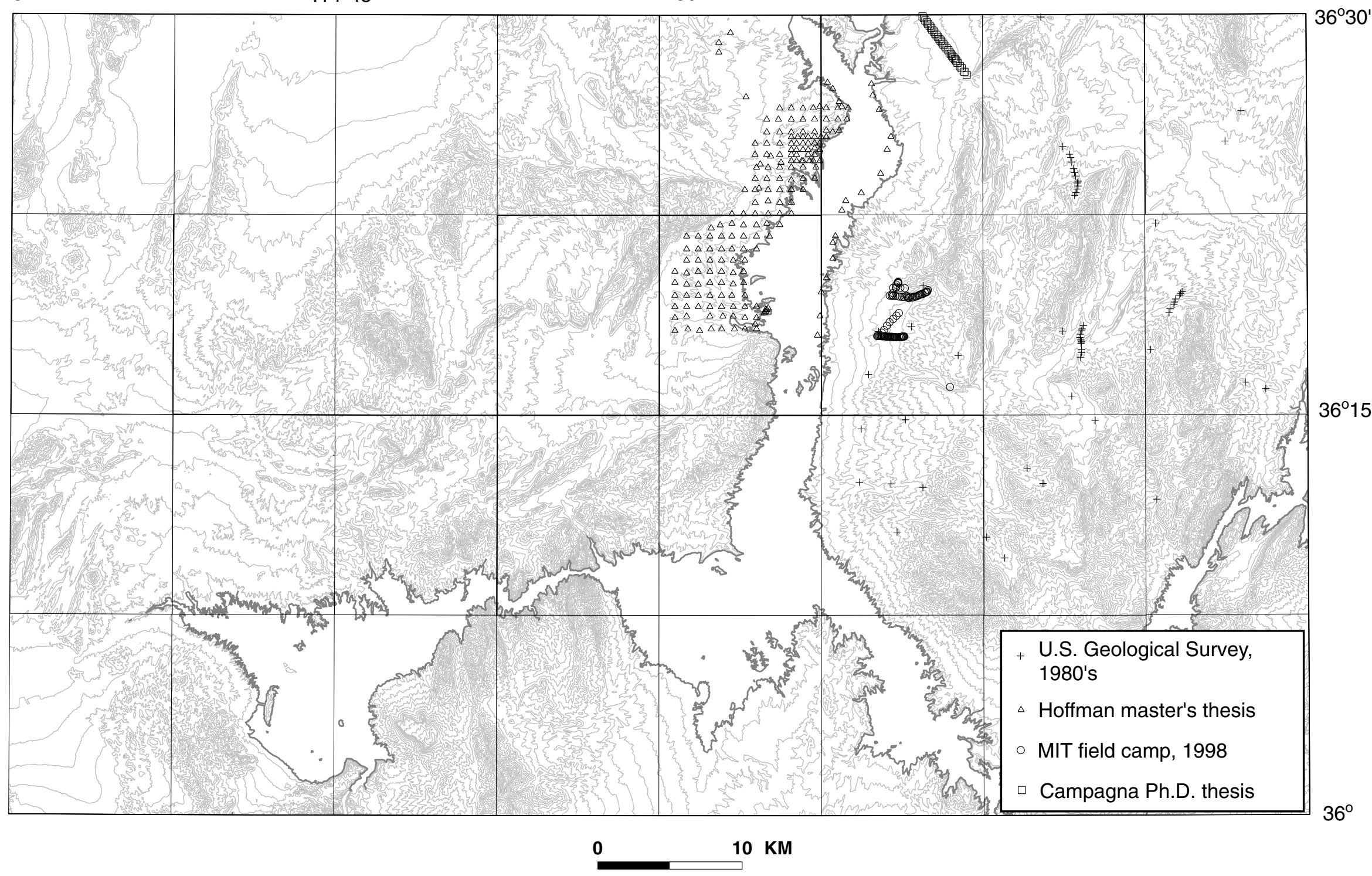

a

Figure 4. Stations compiled from various sources. 
All 811 stations collected by the USGS were ultimately referenced to LVGS. LVGS is in front

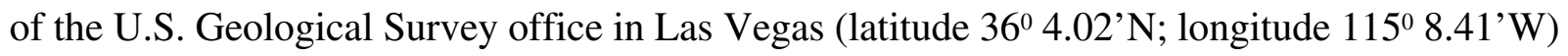
and has an observed gravity value of $979593.62 \mathrm{mGal}$ based on ties to CPA (Ponce and Oliver, 1981; observed gravity value of $979522.22 \mathrm{mGal}$ ), a gravity base station that is part of the Mt. Charleston calibration loop. Secondary base stations were set up in Overton (OVER; 36 33.00'N; $114^{\circ} 27.20^{\prime} \mathrm{W}$; $979656.90 \mathrm{mGal}$ ), the Lake Mead Visitor Center (LMVC; $36^{0} 0.58^{\prime} \mathrm{N} ; 1^{\circ}$ 47.75'N; $979623.33 \mathrm{mGal}$ ) and the Meadview Community Center (MVCC; 35 58.02'N; 114 5.53'W; 979492.35 mGal). MESQ (Mesquite, 360 48.22'N; $114^{\circ}$ 4.03'W; 979624.12 mGal) was also used for stations collected east of the Overton Arm. Conversion of readings to milligals was made using factory calibration constants and a calibration factor which varies with each gravity meter and has been determined by multiple readings over the Mt. Hamilton calibration loop east of San Jose, California (Barnes and others, 1969). Observed gravity values were based on an assumed linear drift between successive base readings. Errors in the observed gravity data are generally $0.05 \mathrm{mGal}$ or better, based on repeat readings. Vertical and horizontal control of position was mostly provided by small, portable Global Positioning Systems (GPS). A base GPS unit was used to record variations in the satellite signals, and these variations were applied to the roving GPS unit. The horizontal locations calculated by GPS were accurate at a scale of 1:24,000. Printed elevations on 1:24,000-scale maps were preferentially used over the GPS elevations; however, a comparison of GPS and map elevations rarely exceeded 10 feet. The two detailed profiles east of Overton Arm were established using a differential system of Trimble Real Time Kinematic (RTK) Series 4400 GPS receivers, which gives elevations that are accurate to within 1 foot. Elevations for stations along the perimeter of the lake are also quite accurate (to within a foot) because they are referenced to the lake level.

The datum of observed gravity for all 1573 gravity stations is the International Gravity Standardization Net of 1971 (IGSN 71) as described by Morelli (1974); the reference ellipsoid used is the Geodetic Reference System 1967 (GRS67; International Association of Geodesy, 1971). For stations collected by the MIT field camp and Campagna, we reoccupied several of their stations to determine the appropriate datum shift. The observed gravity data were reduced to freeair anomalies using standard formulas (e.g. Telford and others, 1976). Bouguer, curvature, and terrain corrections (to a distance of $166.7 \mathrm{~km}$; Plouff, 1977) were applied to the free-air anomaly at each station to determine the complete Bouguer anomalies at a standard reduction density of 2.67 $\mathrm{g} / \mathrm{cm}^{3}$. An isostatic correction was then applied to remove the long-wavelength effect of deep crustal and/or upper mantle masses that isostatically support regional topography. The isostatic correction assumes an Airy-Heiskanen model (Heiskanen and Vening-Meinesz, 1958) of isostatic compensation; compensation is achieved by varying the depth of the model crust-mantle interface, using the following parameters: a sea-level crustal thickness of $25 \mathrm{~km}$, a crust-mantle density 
contrast of $0.40 \mathrm{~g} / \mathrm{cm}^{3}$, and a crustal density of $2.67 \mathrm{~g} / \mathrm{cm}^{3}$ for the topographic load. These parameters were used because (1) they are consistent with model parameters used for isostatic corrections computed for nearby California (Roberts and others, 1990), and (2) changing the model parameters does not significantly affect the resulting isostatic anomaly (Simpson and others, 1986). The computer program ISOCOMP (Jachens and Roberts, 1981) directly calculates the attraction of an Airy-Heiskanen root by summing the attraction of individual mass prisms making up the root and thus calculating the isostatic correction; the resulting isostatic residual gravity values should reflect lateral variations of density within the mid- to upper crust.

\section{Effects of Lake Mead}

The terrain corrections described above assume that the lake is filled with rock with a density of $2.67 \mathrm{~g} / \mathrm{cm}^{3}$. Here we calculate the correction to replace the lake with water. We digitized bathymetric contours from USGS 1:24,000 maps so we could calculate the gravitational effect of the lake on the gravity stations. The bathymetric data were gridded at a $220-\mathrm{m}$ spacing and merged with the 30-meter digital elevation models of the surrounding topography (Fig. 5). We used a three-dimensional modeling program to calculate the gravity effect of the water in the reservoir. The top surface of the lake was fixed to $366 \mathrm{~m}$ above sea level (normal pool elevation of the lake) and our 220-m grid of the bathymetry provided the bottom surface. The calculation of the gravity is based on a density contrast of $-1.67 \mathrm{~g} / \mathrm{cm}^{3}$ between water and the rock density $\left(2.67 \mathrm{~g} / \mathrm{cm}^{3}\right)$. This adjusts the terrain corrections, which were based on the lake being filled with rock. The grid of the gravity produced by the lake was upward continued by $220 \mathrm{~m}$ to reduce oscillations in the calculation and produce the gravity map (Fig. 6). The effects of the lake are restricted to the lake and its edges. The greatest effects are centered in the Boulder and Middle Basins ( $-8 \mathrm{mGal}$ ) and within Boulder and Virgin canyons (up to $-16 \mathrm{mGal}$ ). However, because our gravity stations are measured on the lake's edge and several islands, the greatest adjustment to an individual station is about $-5 \mathrm{mGal}$.

\section{Physical Property Measurements}

We performed 290 density and magnetic susceptibility measurements (Fig. 7; Table 2) on rock samples, ranging in size from thin-section chips to boulder-sized blocks collected for paleomagnetic data. Densities were measured with an electronic precision balance (Sartorius Model 1264 MP) and susceptibilities, with a KT-5 susceptibility meter. Grain densities ranged from 1.96 (Tertiary ignimbrite) ot $3.27 \mathrm{~g} / \mathrm{cm}^{3}$ (Precambrian ultramafic rock), averaging 2.66 $\mathrm{g} / \mathrm{cm}^{3}$. We grouped the densities by age of the sample, because, in general, density increases with age. The densest rocks are Precambrian, averaging $2.82 \mathrm{~g} / \mathrm{cm}^{3}(\mathrm{~N}=87)$. Most of these samples were of the crystalline basement. Paleozoic sedimentary rocks have an average density of 2.69 

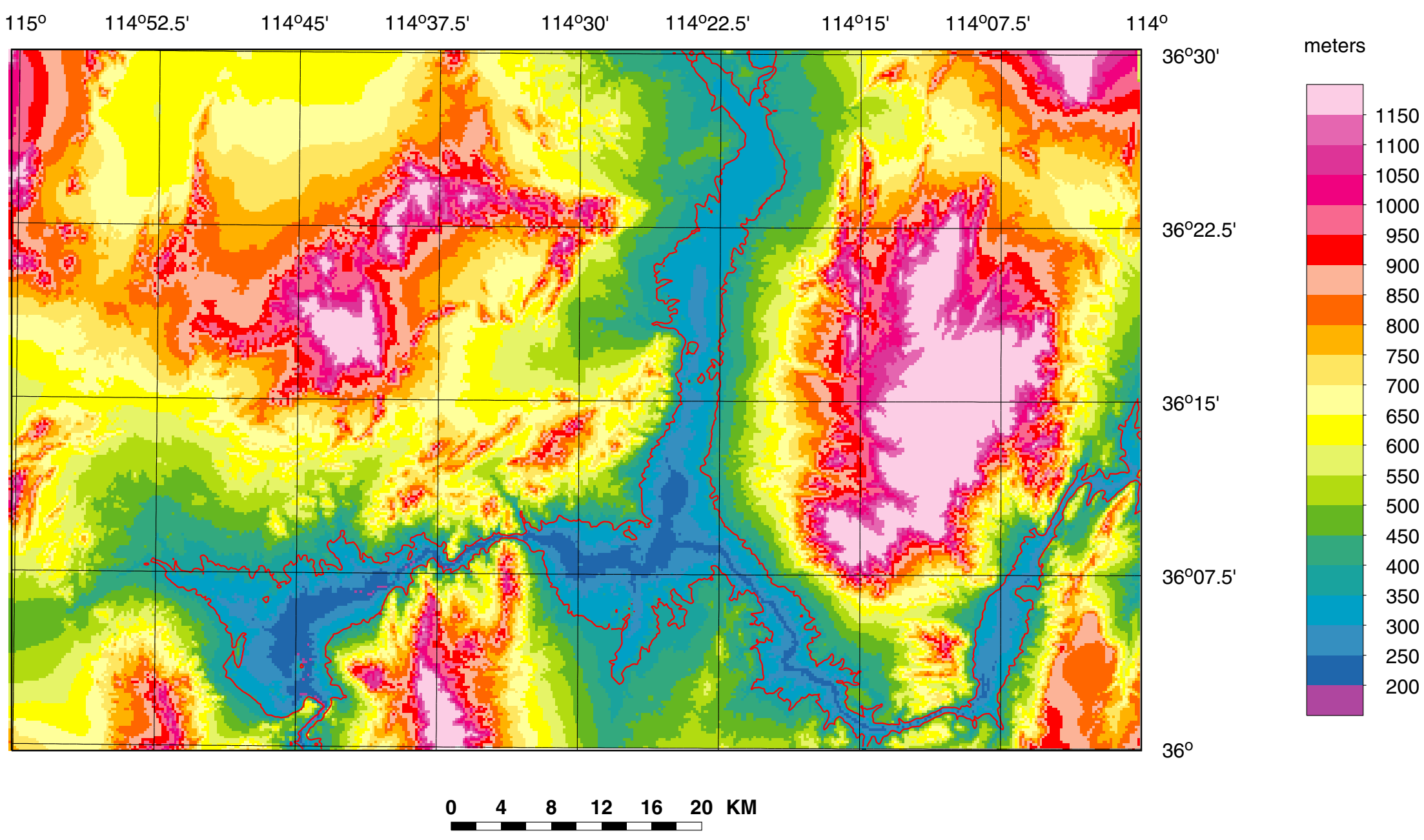

Figure 5. Bathymetry of Lake Mead merged with topography. Red line is the $366 \mathrm{~m}$ contour, the normal pool elevation of the reservoir. 


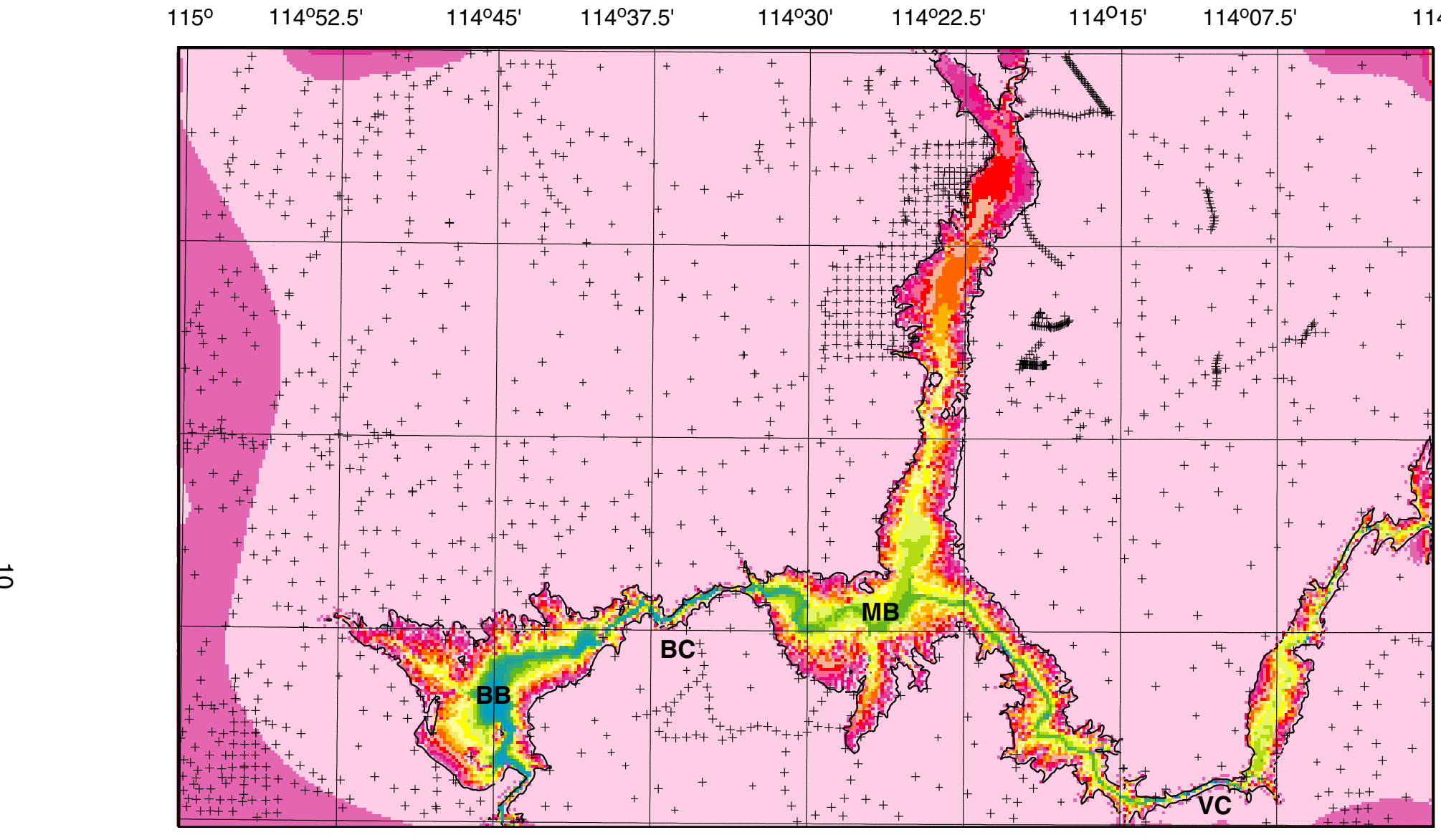

$36^{\circ} 30^{\prime}$

$36^{\circ} 22.5^{\prime}$

Figure 6. Gravity field of Lake Mead using the normal pool elevation of $366 \mathrm{~m}$ for the top surface, bathymetry for the bottom surface and a density contrast of $-1.67 \mathrm{~g} / \mathrm{cm}^{3}$. Original terrain corrections assumed that the lake was filled with rock (density of $\left.2.67 \mathrm{~g} / \mathrm{cm}^{3}\right)$. Crosses are all gravity stations in the Lake Mead quadrangle. BB, Boulder basin; BC, Boulder canyon; MB, Middle Basin; VC, Virgin Canyon. 


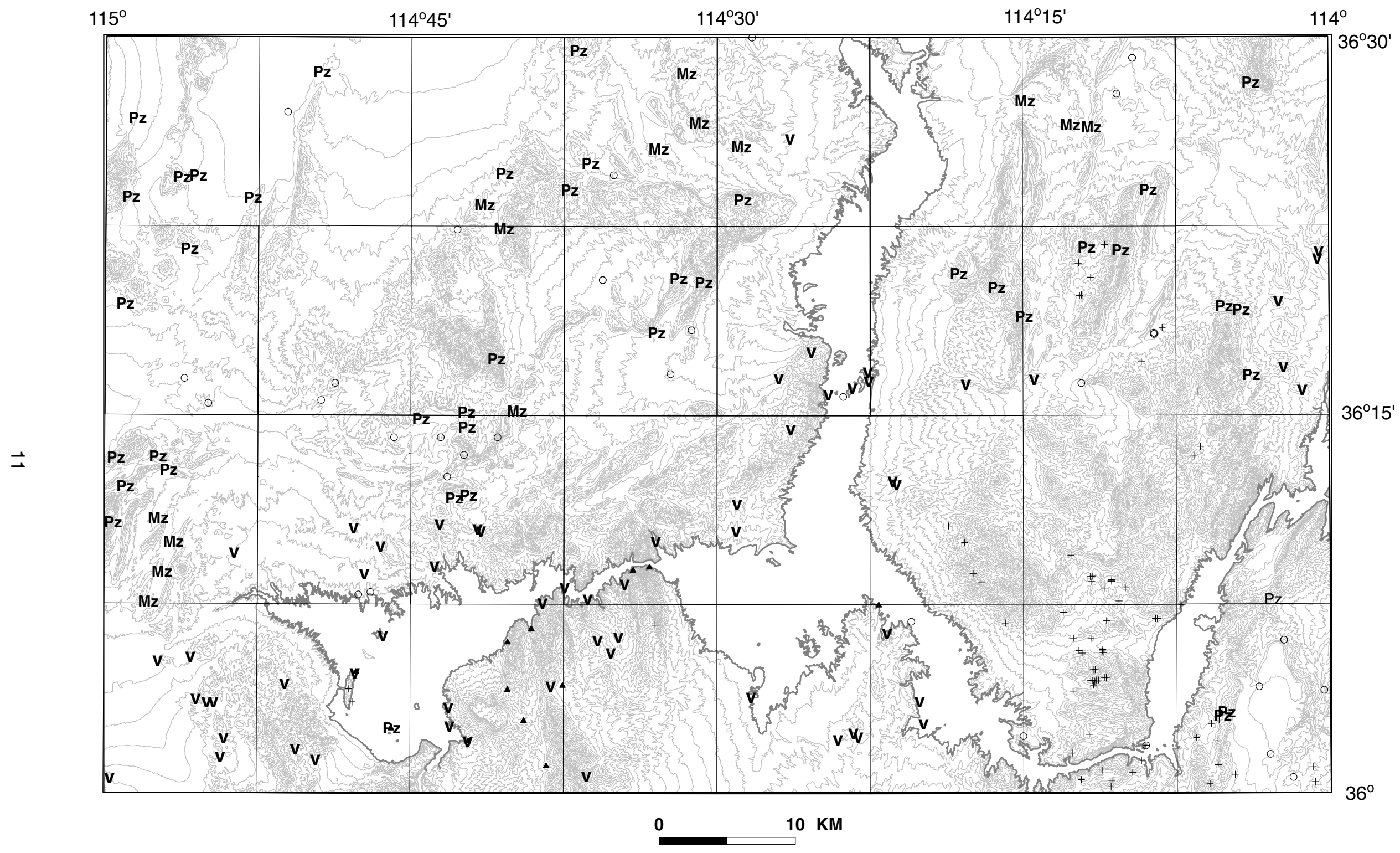

Figure 7. Locations of physical property measurements Crosses, Precambrian rocks; Pz, Paleozoic rocks; $\mathrm{Mz}$, Mesozoic rocks, circles, Cenozoic sedimentary rocks; v's, Tertiary volcanic rocks, and solid triangles, Tertiary intrusive rocks. 
$\mathrm{g} / \mathrm{cm}^{3}(\mathrm{~N}=48)$, although dolomites are characterized by higher densities $\left(2.82 \mathrm{~g} / \mathrm{cm}^{3}\right)$. Mesozoic rocks have an average density of $2.51 \mathrm{~g} / \mathrm{cm}^{3}(\mathrm{~N}=14)$ and Tertiary sedimentary rocks, $2.48 \mathrm{~g} / \mathrm{cm}^{3}$ ( $\mathrm{N}=36)$. Tertiary volcanic rocks have widely varying densities, from 1.96 (ignimbrite) to 2.93 $\mathrm{g} / \mathrm{cm}^{3}$ (basalt). Their average density is $2.59 \mathrm{~g} / \mathrm{cm}^{3}(\mathrm{~N}=78)$ whereas Tertiary intrusive rocks are, on average, slighly more dense (average $2.63 \mathrm{~g} / \mathrm{cm}^{3} ; \mathrm{N}=25$ ). We also measured saturated bulk densities for the samples to constrain the in situ density of the rock below the water table.

Table 2. Rock densities, in $\mathrm{g} / \mathrm{cm}^{3}$ and susceptibilites $\left(10^{-3} \mathrm{cgs}\right.$ units $)$

\begin{tabular}{|c|c|c|c|c|}
\hline No. Samples Density* Range & $\begin{array}{l}\text { Average } \\
\text { Density* }\end{array}$ & $\begin{array}{l}\text { Average Saturated } \\
\text { Bulk Density }\end{array}$ & $\begin{array}{l}\text { Susceptibility } \\
\text { Range }\end{array}$ & $\begin{array}{c}\text { Average } \\
\text { Susceptibility }\end{array}$ \\
\hline Precambrian crystalline rocks & & & & \\
\hline $\begin{array}{cc}87 & 2.54-3.27 \\
\text { Paleozoic } & \text { sedimentary rocks }\end{array}$ & 2.82 & 2.79 & $0.00-3.50$ & 0.50 \\
\hline $\begin{array}{cc}48 & 2.53-2.84 \\
\text { Mesozoic } & \text { sedimentary rocks }\end{array}$ & 2.69 & 2.65 & $0.00-0.02$ & 0.00 \\
\hline $\begin{array}{cc}14 & 2.21-2.69 \\
\text { Cenozoic } & \text { sedimentary rocks }\end{array}$ & 2.51 & 2.41 & $0.00-0.01$ & 0.00 \\
\hline $\begin{array}{cc}36 & 2.15-2.63 \\
\text { Cenozoic } & \text { volcanic rocks }\end{array}$ & 2.48 & 2.34 & $0.00-0.29$ & 0.02 \\
\hline $\begin{array}{cc}78 & 1.96-2.93 \\
\text { Cenozoic } & \text { intrusive rocks }\end{array}$ & 2.59 & 2.51 & $0.00-4.40$ & 0.46 \\
\hline $\begin{array}{ll}25 & 2.41-2.78 \\
\end{array}$ & 2.63 & 2.58 & $0.00-1.12$ & 0.40 \\
\hline
\end{tabular}

Susceptibility data show that sedimentary rocks, regardless of age, are essentially non-magnetic (Table 2). Precambrian crystalline rocks, on average, are the most magnetic lithology, followed by Tertiary volcanic and intrusive rocks. These data suggest that the only sources for the aeromagnetic anomalies in the Lake Mead quadrangle are Precambrian crystalline or Tertiary volcanic and intrusive rocks.

\section{Conclusions}

The main sources of error in the gravity data are inaccurate elevations and/or inaccurate terrain corrections. Errors associated with terrain corrections may be 5 to 10 percent of the value of the total terrain correction. The average error based on the average terrain correction $(1.32 \mathrm{mGal})$ is thus about $0.1 \mathrm{mGal}$, but in the most rugged areas of the Gold Butte, the individual errors may be as large as $3 \mathrm{mGal}$. Those stations ringing Lake Mead have an additional source of error in the adjustment to the terrain correction. The largest additional error may be as high as $0.5 \mathrm{mGal}(10 \%$ of $5 \mathrm{mGal}$, thelargest adjustment). Errors resulting from elevation uncertainties are probably less than $0.5 \mathrm{mGal}$ for most of the data because the majority of the stations are at or near bench marks and spot and surveyed elevations, which are accurate to about 0.2 to $3 \mathrm{~m}$. Measurements for which elevations were controlled by contour interpolation are expected to have errors of up to 1.2 
mGal. In general, the total uncertainties for the data shown on the map (Fig. 8) are estimated to be less than $2 \mathrm{mGal}$, although in many areas the data are considerably more accurate.

\section{Acknowledgments}

We would like to thank Sue Beard (USGS, Flagstaff, Ariz.), Keith Howard (USGS, Menlo Park, Calif.), Mel Kuntz (USGS, Denver, Colo.), and Jim Faulds (Nevada Bureau of Mines and Geology) for providing us rock samples (with corresponding locations and descriptions) for many of the physical property measurements. We also thank the Las Vegas Valley Water District for financial assistance for gravity stations in the Henderson and Nellis Air Force Base areas. Robert L. Morin and David Ramsey provided useful reviews of the data and manuscript. 


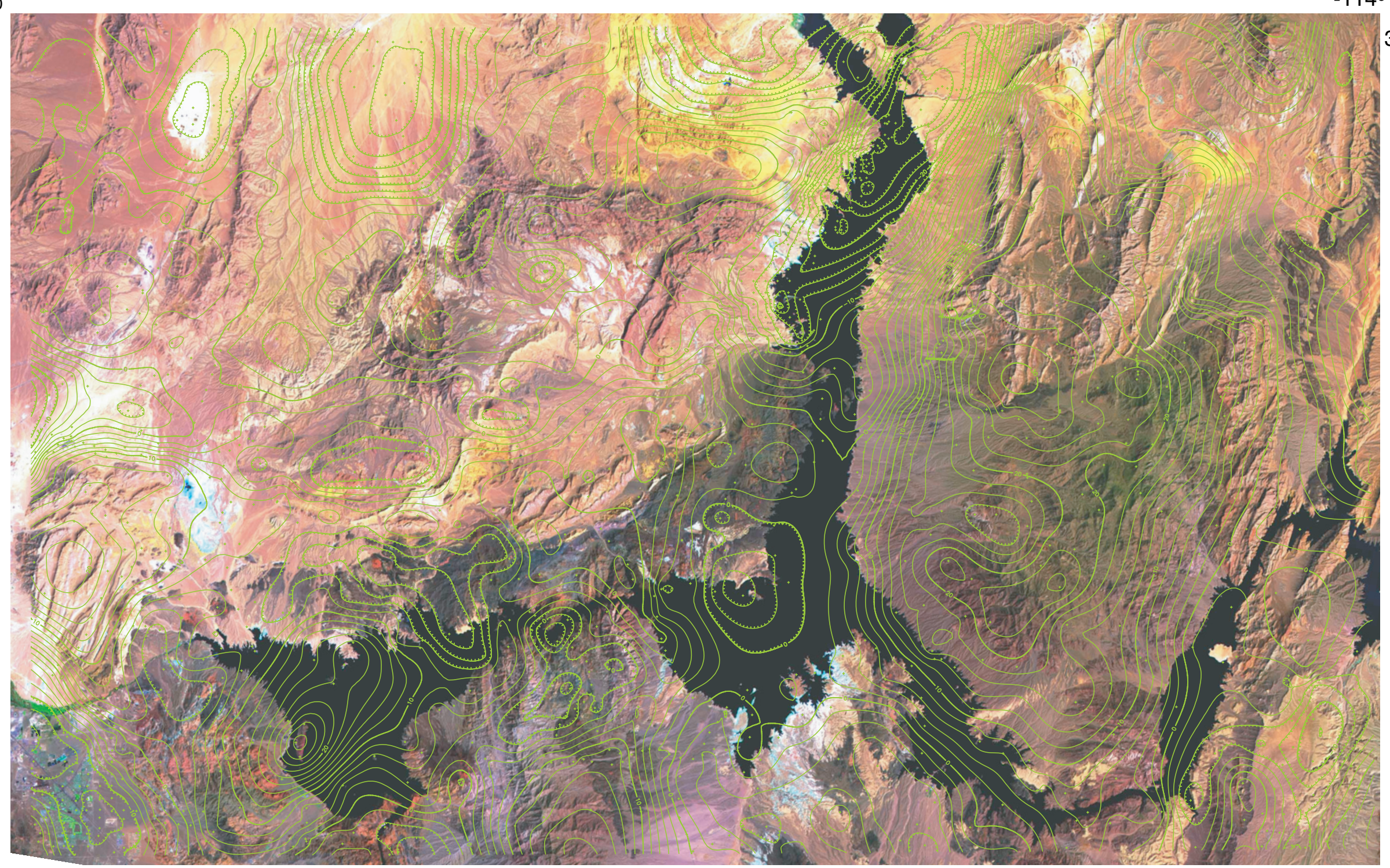

Figure 8. Isostatic gravity contours (adjusted for the effect of the lake) on TM image of the Lake Mead 30 by 60 minute quadrangle. Contour interval, $2 \mathrm{mGal}$. Contours approximately registered to image. 


\section{References}

Barnes, D.F., Oliver, H.W., and Robbins, S.L., 1969, Standardization of gravimeter calibrations in the Geological Survey: Eos (American Geophysical Union Transactions), v. 50, no. 10, p. 626-627.

Campagna, D.J., 1990, The Lake Mead fault system and the Las Vegas valley shear zone: Strikeslip faulting and associated deformation in the Basin and Range, southeastern Nevada: Ph.D. dissertation, Purdue University, Lafayette, Indiana, 79 p.

Heiskanen, W.A., and Vening-Meinesz, F.A., 1958, The Earth and its gravity field: New York, McGraw-Hill Book Company, Inc., 470 p.

Hoffman, David Gordon, 1978, Gravity study of northern Virgin Valley salt deposits, Clark County, Nevada: University of Washington Master's thesis, 63 p.

International Union of Geodesy and Geophysics, 1971, Geodetic reference system 1967: International Association of Geodesy Special Publication no. 3, 116 p.

Jachens, R.C., and Roberts, C.W., 1981, Documentation of a Fortran program, 'ISOCOMP', for computing isostatic residual gravity: U.S. Geological Survey Open-File Report 81-574, $26 \mathrm{p}$.

Kane, M.F., Healey, D.L., Peterson, D.L., Kaufmann, H.E., and Reidy, D., 1979, Bouguer gravity map of Nevada-Las Vegas sheet: Nevada Bureau of Mines and Geology Map 61, scale 1:250,000.

Morelli, Carlo. (ed.), 1974, The International gravity standardization net 1971: International Association of Geodesy Special Publication no. 4, 194 p.

Plouff, Donald, 1977, Preliminary documentation for a FORTRAN program to compute gravity terrain corrections based on topography digitized on a geographic grid: U.S. Geological Survey Open-File Report 77-535, 45 p.

Ponce, D.A., and Oliver, H.W., 1981, Charleston Peak gravity calibration loop, Nevada: U.S. Geological Survey Open-File Report 81-985, 20 p.

Roberts, C.W., Jachens, R.C., and Oliver, H.W., 1990, Isostatic residual gravity map of California and offshore southern California: California Division of Mines and Geology, Geologic Data Map No. 7, scale 1:750,000.

Simpson, R.W., Jachens, R.C., Blakely, R.J., and Saltus, R.W., 1986, A new isostatic gravity map of the conterminous United States with a discussion on the significance of isostatic residual anomalies: Journal of Geophysical Research, v. 91, p. 8348-8372.

Telford, W.M., Geldart, L.O., Sheriff, R.E., and Keyes, D.A., 1976, Applied Geophysics: New York, Cambridge University Press, 960 p. 